\title{
LAST ICE AGE MILLENNIAL SCALE CLIMATE CHANGES RECORDED IN HUON PENINSULA CORALS
}

\begin{abstract}
Yusuke Yokoyama ${ }^{1,2} \bullet$ Tezer M Esat $^{1,3} \cdot$ Kurt Lambeck $^{1} \bullet$ L Keith Fifield $^{4}$
ABSTRACT. Uranium series and radiocarbon ages were measured in corals from the uplifted coral terraces of Huon Peninsula (HP), Papua New Guinea, to provide a calibration for the ${ }^{14} \mathrm{C}$ time scale beyond $30 \mathrm{ka}$ (kilo annum). Improved analytical procedures, and quantitative criteria for sample selection, helped discriminate diagenetically altered samples. The base-line of the calibration curve follows the trend of increasing divergence from calendar ages, as established by previous studies. Superimposed on this trend, four well-defined peaks of excess atmospheric radiocarbon were found ranging in magnitude from $100 \%$ to $700 \%$, relative to current levels. They are related to episodes of sea-level rise and reef growth at HP. These peaks appear to be synchronous with Heinrich Events and concentrations of ice-rafted debris found in North Atlantic deepsea cores. Relative timing of sea-level rise and atmospheric ${ }^{14} \mathrm{C}$ excess imply the following sequence of events: An initial sealevel high is followed by a large increase in atmospheric ${ }^{14} \mathrm{C}$ as the sea-level subsides. Over about 1800 years, the atmospheric radiocarbon drops to below present ambient levels. This cycle bears a close resemblance to ice-calving episodes of Dansgaard-Oeschger and Bond cycles and the slow-down or complete interruption of the North Atlantic thermohaline circulation. The increases in the atmospheric ${ }^{14} \mathrm{C}$ levels are attributed to the cessation of the North Atlantic circulation.
\end{abstract}

\section{INTRODUCTION}

Calibration of the radiocarbon time scale over the last $\sim 11$ ka has been secured using tree-ring chronology (Becker and Kromer 1993). Data beyond this period, however, are not extensive (Bard 1998). ${ }^{14} \mathrm{C}$ dating and calendar ages $\left({ }^{230} \mathrm{Th} /{ }^{234} \mathrm{U}\right.$ dating) of corals can be determined directly (Bard et al. 1998), an advantage that is particularly relevant for time periods beyond $\sim 25 \mathrm{ka}$. Coral samples from drill-cores offshore from Barbados (Bard et al. 1990a, 1990b, 1993, 1998) and from Huon Peninsula (Edwards et al. 1993) have been dated with accelerator mass spectrometry (AMS ${ }^{14} \mathrm{C}$; Nelson et al. 1977) and thermal ionization mass spectrometry (TIMS, Th/U; Edwards et al. 1987). Where there is an overlap in calendar ages determined from tree-rings and U/Th dating, the two methods are in good agreement (Bard et al. 1998; Kromer and Spurk 1998).

We have extended the previous coral-based ${ }^{14} \mathrm{C}$ calibration from $30 \mathrm{ka}$ to beyond $50 \mathrm{ka}$ using mass spectrometric ${ }^{14} \mathrm{C}$ and $\mathrm{Th} / \mathrm{U}$ dating techniques on corals collected from Reefs II and III at Huon Peninsula, Papua New Guinea (Figure 1). In this paper, we report the new results and discuss possible causes of large excursions of atmospheric ${ }^{14} \mathrm{C}$ recorded in these corals. Some $\mathrm{Th} / \mathrm{U}$ ages were previously available for a subset of the same corals (Chappell et al. 1996).

\section{MATERIALS AND METHODS}

Most of the corals used in this study were collected from Bobongara (Bobo) and Kanzarua (Kanz) sections that have some of the highest uplift rates at HP (Figure 1). A number of $\mathrm{Th} / \mathrm{U}$ dates and descriptions of sample locations have been provided by Chappell et al. (1996). General TIMS Useries dating methods were described by Edwards et al. (1987), and procedures used in the present work were previously documented by Stirling et al. (1995) and Esat, (1995). For ${ }^{14} \mathrm{C}$ dating, $\mathrm{CO}_{2}$ extracted from corals was converted to graphite, in the presence of $\mathrm{H}_{2}$, using Fe powder as a catalyst

\footnotetext{
${ }^{1}$ Research School of Earth Sciences, The Australian National University, Canberra, ACT 0200, Australia

${ }^{2}$ Present address: Space Sciences Laboratory, University of California at Berkeley and Lawrence Livermore National

Laboratory, P.O. Box 808, L-202, Livermore, CA94550 USA. Email: yusuke@ ssl.berkeley.edu.

${ }^{3}$ Department of Geology, The Australian National University, Canberra, ACT 0200, Australia

${ }^{4}$ Department of Nuclear Physics, Research School of Physical Sciences and Engineering, The Australian National University, Canberra, ACT 0200, Australia
} 


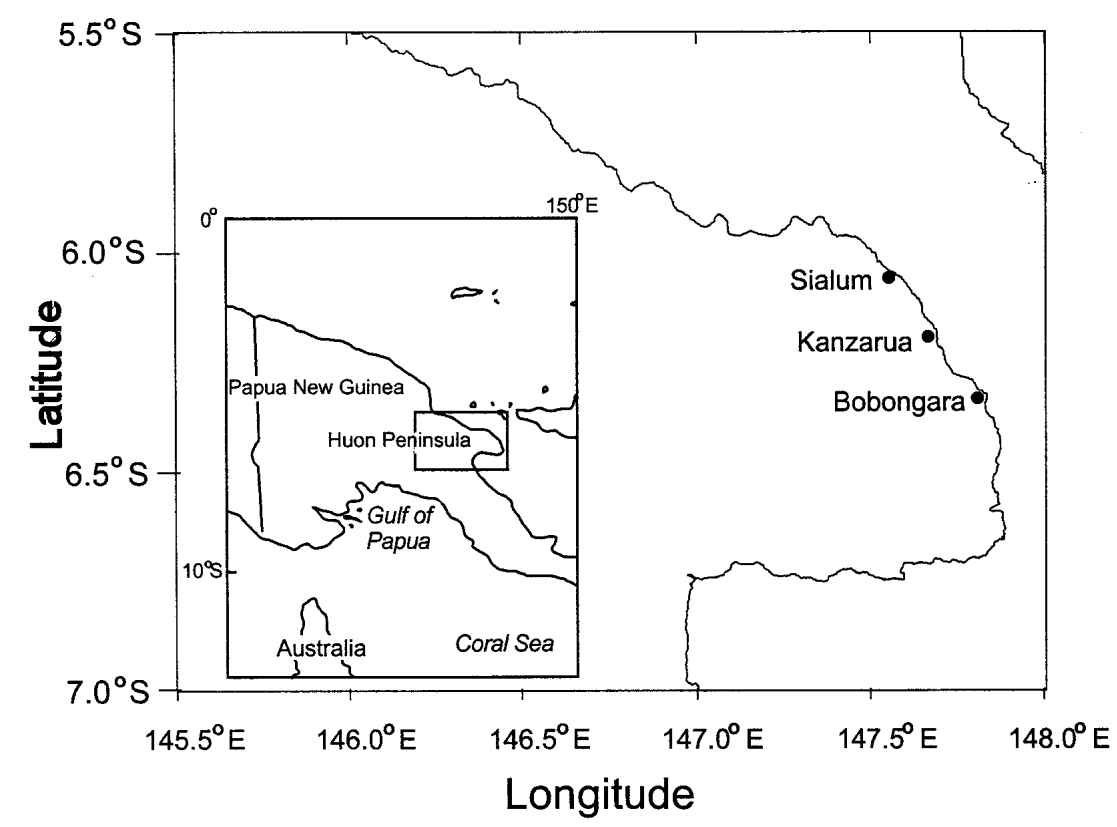

Figure 1 Location of Kanzarua and Bobongara reef sections at Huon Peninsula, Papua New Guinea.

(Vogel et al. 1984), and is described below in detail. Particulars of AMS dating at the Australian National University can be found in Fifield et al. (1993).

The graphitization method employed in the present study reliably produces high graphite yields $(>85-95 \%)$. Water is formed as the byproduct of the reaction:

$$
2 \mathrm{H}_{2}+\mathrm{CO}_{2} \underset{625^{\circ} \mathrm{C}}{\stackrel{(\mathrm{Fe})}{\Rightarrow}} \mathrm{C}+2 \mathrm{H}_{2} \mathrm{O}
$$

The addition of dry-ice cold traps attached to the reaction vessel, efficiently trapped water vapor away from the sample and even higher graphite yields ( 100\%) could be achieved.

To obtain approximately $1-1.5 \mathrm{mg}$ of graphite, $\sim 1.2-1.8 \mathrm{mg}$ of pre-reduced 325 mesh iron powder was typically used resulting in $\mathrm{C}: \mathrm{Fe}$ ratio of 1 to 1.2 . A weighed vycor-glass thimble cup $(6 \mathrm{~mm}$ diameter and $\sim 1 \mathrm{~cm}$ long) containing the iron powder was placed in a larger diameter vycor-glass tube ( $9 \mathrm{~mm}$ diameter and $\sim 15 \mathrm{~cm}$ long) and labelled. All vycor glassware was precleaned ultrasonically with distilled water and baked overnight at $900{ }^{\circ} \mathrm{C}$. The reaction tube and connecting pieces were cleaned in 1:1 $\mathrm{HNO}_{3}$ and rinsed with distilled water, then stored in an oven at $\sim 60{ }^{\circ} \mathrm{C}$ until needed. Phosphoric acid (85\%) was concentrated on a hotplate with an equal amount of $\mathrm{H}_{2} \mathrm{O}_{2}(30 \%)$ to oxidize and remove organic impurities.

To reduce the possibility of contamination during the $\mathrm{CO}_{2}$-graphite conversion we strived to exclude all sources of organic contamination. For this purpose, an all-metal high-vacuum system was constructed with strict control protocol on its use, including the type and age of samples allowed to be processed. The conversion line was made using 0.25-inch stainless steel tubing with Swage-Lock ${ }^{\circledR}$ 
joints and stainless-steel bellow valves. All of the component parts were cleaned to remove organic residues and baked under vacuum for extended periods. The line is evacuated using a turbo-molecular pump with a liquid nitrogen trap to prevent oil contamination from the pump. A vacuum of better than $10^{-4}$ Torr can be maintained during sample processing.

The vacuum was monitored using two thermocouple gauges. Quantitative $\mathrm{CO}_{2}$ and $\mathrm{H}_{2}$ pressures were measured by two pressure transducers, Baratron ${ }^{\circledR}$, which have accuracies of $\pm 0.05 \%$ and $\pm 0.5 \%$. The more precise Baratron ${ }^{\circledR}$, was used for low-pressure measurements to monitor the yield of gases evolved from the sample, within a calibrated volume, and the other Baratron ${ }^{\circledR}$, which has a higher pressure capacity, was used to monitor $\mathrm{H}_{2}$ pressure during the reduction of $\mathrm{Fe}$ powder. The combined volume of the Baratron ${ }^{\circledR}$, sample-gas storage vessel, and connecting spaces was calibrated using $\mathrm{CO}_{2}$ produced from precisely weighed amounts of ANU sucrose.

Coral samples were inspected under an optical microscope. For each sample, two thin sections were prepared along the coral longitudinal and latitudinal growth axes. In general, secondary alteration was present at the interstices but not within wall structures.

Calcite content of each sample was determined from X-ray powder diffraction (XRD) spectra. The measurements utilised $\mathrm{Cu}-\mathrm{K} \alpha$ radiation $(40 \mathrm{kV}, 30 \mathrm{~mA})$ and a scintillation counter. The scan rate was $2^{\circ} 2^{\prime \prime}$ per minute. Approximately $300 \mathrm{mg}$ of powdered coral was used for each test. The detection limit for calcite was about 2\% (Klug and Alexander 1974).

\section{Precleaning of Samples}

Corals were inspected under a magnifier and physically cleaned using a dental drill to remove interstitial structures other than walls. The samples were cleaned with distilled water in an ultrasonic bath. They were then dried in an oven $\left(\sim 40-60{ }^{\circ} \mathrm{C}\right)$ and weighed. The minimum required amount of $\mathrm{CaCO}_{3}$ to yield $1 \mathrm{mg}$ of carbon is approximately $8.5 \mathrm{mg}$. However, we used larger sample sizes (200-300 mg), and step-wise selective dissolution.

\section{$\mathrm{CO}_{2}$ Production and Purification}

In the present study, samples in the age range 30-60 ka were collected from Reef II and Reef III, including sub-reefs, at Huon Peninsula (Chappell et al. 1996). In addition to textural investigations and XRD measurements, all samples were partially dissolved in several steps, but in a much more severe fashion compared to that previously attempted by Burr et al. (1993). Partial dissolution was first attempted by Bard et al. (1990c); however, its effectiveness was systematically demonstrated later by Burr et al. (1993) using corals older than $70 \mathrm{ka}$ from Barbados and Huon Peninsula. They performed XRD measurements, bulk sample ${ }^{14} \mathrm{C}$ dating, and ${ }^{14} \mathrm{C}$ dating following step-wise dissolution. They concluded that the first $50 \%$ of acid etching effectively removed secondary, younger age carbon (Burr et al. 1993). In the present study, the first 50\% of the coral was etched and discarded, and the rest of the sample was dissolved in three or more aliquots. Each aliquot was AMS dated so that at least three AMS ${ }^{14} \mathrm{C}$ ages were produced for every sample (Table 1).

Generally, contamination comes from extraneous material containing younger or modern carbon, which shifts "true" ${ }^{14} \mathrm{C}$ ages to younger values. This could occur not only during the laboratory process, but also in the natural environment through diagenesis and recrystallization. Step-wise selective dissolution could thus help to identify contaminated samples.

The present reaction vessel was designed to facilitate selective dissolution. It consisted of three compartments, the main chamber held the sample, and two accessory branches contained phosphoric acid. 
Table 1 Radiocarbon results

\begin{tabular}{|c|c|c|c|c|c|c|c|}
\hline $\begin{array}{l}\text { Lab code }^{\mathrm{a}} \\
\text { (ANUA-) }\end{array}$ & Sample & $\begin{array}{c}\text { Dissolved } \\
\text { percent }\end{array}$ & $\mathrm{pMC}$ & $\begin{array}{c}{ }^{14} \mathrm{C} \text { age }{ }^{b} \\
(\mathrm{BP})\end{array}$ & $\begin{array}{l}\text { Error }^{\mathrm{c}} \\
\text { (year) }\end{array}$ & $\begin{array}{l}\text { Error }^{\mathrm{c}} \\
\text { (year) }\end{array}$ & $\begin{array}{c}\text { Calcite }^{\mathrm{d}} \\
\%\end{array}$ \\
\hline 3607 & LIG coral & $0-17$ & $0.74 \pm 0.13$ & 39,460 & +1500 & -1270 & \\
\hline 3608 & (Favid) & $26-30$ & $0.25 \pm 0.05$ & 48,230 & +1880 & -1520 & \\
\hline 3609 & & $34-49$ & $0.21 \pm 0.03$ & 49,450 & +1310 & -1120 & \\
\hline 3610 & & $50-53$ & $0.28 \pm 0.05$ & 47,250 & +1520 & -1280 & \\
\hline 3611 & & $65-70$ & $0.21 \pm 0.04$ & 49,490 & +1660 & -1380 & \\
\hline 3612 & & $71-100$ & $0.26 \pm 0.04$ & 47,970 & +1200 & -1040 & \\
\hline OZD-535 & & $0-100$ & $0.52 \pm 0.18$ & 42,300 & +3410 & -2390 & 2.0 \\
\hline 10017 & Tridacna A & $0-17.2$ & $1.03 \pm 0.08$ & 36,760 & +640 & -600 & \\
\hline 10018 & & $17.2-30.5$ & $0.61 \pm 0.07$ & 41,020 & +980 & -870 & \\
\hline 10019 & & $45.6-73.2$ & $0.38 \pm 0.05$ & 44,830 & +1150 & -1010 & \\
\hline 10020 & & $73.2-100$ & $0.27 \pm 0.04$ & 47,420 & +1270 & -1090 & 0 \\
\hline 9928 & Tridacna B & $50.1-67.2$ & $0.31 \pm 0.05$ & 46,350 & +1340 & -1150 & \\
\hline 9929 & & $67.2-80.5$ & $0.34 \pm 0.06$ & 45,710 & +1590 & -1330 & \\
\hline 9930 & & $80.5-100$ & $0.29 \pm 0.05$ & 46,880 & +1500 & -1260 & 0 \\
\hline 6105 & Kanz 4 & $63.8-76.1$ & $1.50 \pm 0.13$ & 33,730 & +550 & -520 & \\
\hline 6104 & (Favid) & $76.1-88.2$ & $1.51 \pm 0.12$ & 33,660 & +440 & -410 & \\
\hline 6103 & & $88.2-100$ & $1.55 \pm 0.13$ & 33,480 & +540 & -500 & \\
\hline OZD-532 & & $0-100$ & $2.98 \pm 0.21$ & 28,200 & +590 & -550 & 0 \\
\hline 4206 & Kanz 9 & $50.8-65.0$ & $0.44 \pm 0.09$ & 43,630 & +1910 & -1540 & \\
\hline 4207 & (Favid) & $65.0-79.0$ & $0.41 \pm 0.05$ & 44,160 & +950 & -850 & \\
\hline 4208 & & $79.0-100$ & $0.49 \pm 0.12$ & 42,670 & +2320 & -1800 & \\
\hline OZD-533 & & $0-100$ & $1.05 \pm 0.20$ & 36,600 & +1700 & -1400 & 1.0 \\
\hline 7525 & Kanz 11 & $62.3-72.9$ & $1.07 \pm 0.06$ & 36,490 & +490 & -460 & \\
\hline 7526 & (Porites) & $72.9-86.3$ & $1.26 \pm 0.06$ & 35,150 & +420 & -400 & \\
\hline 7527 & & $86.3-100$ & $1.36 \pm 0.07$ & 34,520 & +450 & -420 & $3.3,1.5$ \\
\hline 7528 & Kanz 13 & $47.1-63.0$ & $0.84 \pm 0.05$ & 38,390 & +510 & -480 & \\
\hline 7529 & (Porites) & $63.0-80.3$ & $0.77 \pm 0.05$ & 38,730 & +560 & -520 & \\
\hline 7530 & & $80.3-100$ & $0.77 \pm 0.04$ & 39,050 & +450 & -430 & 0.9 \\
\hline 8202 & Kanz 15 & $60.3-73.9$ & $0.98 \pm 0.09$ & 37,120 & +790 & -720 & \\
\hline 8203 & (Porites) & $73.9-85.9$ & $0.79 \pm 0.11$ & 38,890 & +1220 & -1060 & \\
\hline 8204 & & $85.9-100$ & $1.07 \pm 0.14$ & 36,460 & +1140 & -1000 & 0 \\
\hline 6915 & Kanz U8 & $48.0-64.5$ & $1.49 \pm 0.11$ & 33,800 & +620 & -570 & \\
\hline 6916 & (Porites) & $64.5-81.8$ & $1.47 \pm 0.11$ & 33,930 & +620 & -580 & \\
\hline 6917 & & $81.8-100$ & $1.63 \pm 0.12$ & 33,090 & +600 & -550 & 1.9 \\
\hline 4230 & Kanz U9 & $46.8-58.6$ & $1.63 \pm 0.17$ & 33,080 & +860 & -780 & \\
\hline 4231 & (Favid) & $58.6-72.1$ & $1.24 \pm 0.14$ & 35,280 & +910 & -840 & \\
\hline 4303 & & $72.1-100$ & $1.28 \pm 0.10$ & 35,010 & +750 & -630 & $4.5,1.8$ \\
\hline 4316 & Kanz U10 & $38.6-52.4$ & $2.33 \pm 0.21$ & 30,190 & +680 & -750 & \\
\hline 4312 & (Porites) & $52.4-83.2$ & $1.65 \pm 0.19$ & 32,980 & +980 & -870 & \\
\hline 4307 & & $83.2-100$ & $1.39 \pm 0.11$ & 34,350 & +660 & -610 & 2.2 \\
\hline 6908 & Kanz U11 & $46.3-60.0$ & $2.30 \pm 0.16$ & 30,290 & +600 & -560 & \\
\hline 6909 & (Favid) & $60.0-73.7$ & $2.38 \pm 0.17$ & 30,040 & +590 & -550 & \\
\hline 6910 & & $73.7-100$ & $2.51 \pm 0.17$ & 29,600 & +580 & -540 & 0 \\
\hline OZD-536 & & $0-100$ & $4.33 \pm 0.22$ & 25,200 & +420 & -400 & \\
\hline
\end{tabular}


Table 1 Radiocarbon results (Continued)

\begin{tabular}{|c|c|c|c|c|c|c|c|}
\hline $\begin{array}{l}\text { Lab code }^{\mathrm{a}} \\
\text { (ANUA-) }\end{array}$ & Sample & $\begin{array}{l}\text { Dissolved } \\
\text { percent }\end{array}$ & $\mathrm{pMC}$ & $\begin{array}{c}{ }^{14} \mathrm{C} \text { age }{ }^{b} \\
\text { (BP) }\end{array}$ & $\begin{array}{l}\text { Error }^{\mathrm{c}} \\
\text { (years) }\end{array}$ & $\begin{array}{l}\text { Error }^{\mathrm{c}} \\
\text { (years) }\end{array}$ & $\begin{array}{c}\text { Calcite }^{\mathrm{d}} \\
\%\end{array}$ \\
\hline 4317 & Kanz U12 & $49.6-61.2$ & $2.10 \pm 0.19$ & 31,050 & +760 & -690 & \\
\hline 4308 & (Favid) & $92.0-100$ & $1.84 \pm 0.14$ & 32,100 & +650 & -600 & 0.5 \\
\hline OZD-537 & & $0-100$ & $2.73 \pm 0.23$ & 28,900 & +710 & -650 & \\
\hline 6829 & Kanz U13 & $50.5-61.4$ & $1.84 \pm 0.12$ & 32,100 & +530 & -500 & \\
\hline 4313 & (Favid) & $61.4-71.9$ & $1.07 \pm 0.11$ & 36,440 & +880 & -790 & \\
\hline 4309 & & $71.9-100$ & $1.78 \pm 0.17$ & 32,350 & +800 & -730 & 0.9 \\
\hline OZD-542 & & $0-100$ & $1.91 \pm 0.17$ & 31,800 & +750 & -680 & \\
\hline 6107 & Kanz U14 & $69.3-79.9$ & $1.05 \pm 0.10$ & 36,630 & +800 & -730 & \\
\hline 6108 & (Porites) & $79.9-89.1$ & $0.83 \pm 0.07$ & 38,500 & +700 & -640 & \\
\hline 6109 & & $89.1-100$ & $1.04 \pm 0.08$ & 36,600 & +680 & -630 & 2.5 \\
\hline OZD-540 & & $0-100$ & $1.53 \pm 0.21$ & 33,600 & +1200 & -1030 & \\
\hline 6825 & Kanz U15 & $70.0-80.5$ & $0.97 \pm 0.07$ & 37,210 & +590 & -550 & \\
\hline 6824 & (Favid) & $80.5-89.5$ & $0.94 \pm 0.07$ & 37,490 & +600 & -560 & \\
\hline 6823 & & $89.5-100$ & $1.22 \pm 0.07$ & 35,410 & +500 & -470 & 0.1 \\
\hline 6828 & Kanz U16 & $59.0-73.1$ & $1.91 \pm 0.10$ & 31,810 & +450 & -420 & \\
\hline 6827 & (Porites) & $73.1-86.7$ & $2.04 \pm 0.11$ & 31,290 & +430 & -410 & \\
\hline 6826 & & $86.7-100$ & $1.76 \pm 0.11$ & 32,450 & +510 & -480 & 3.2 \\
\hline 6818 & Kanz A & $47.9-58.2$ & $2.96 \pm 0.14$ & 28,280 & +380 & -360 & \\
\hline 6817 & (Favid) & $58.2-69.0$ & $2.81 \pm 0.16$ & 28,690 & +480 & -450 & \\
\hline 6816 & & $69.0-100$ & $2.90 \pm 0.16$ & 28,440 & +470 & -440 & 1.0 \\
\hline 4209 & Bobo U10 & $56.2-67.7$ & $2.47 \pm 0.16$ & 28,730 & +550 & -510 & \\
\hline 4210 & (Favid) & $67.7-97.4$ & $1.62 \pm 0.12$ & 33,120 & +640 & -590 & 0 \\
\hline 4212 & Bobo U11 & $51.9-61.7$ & $3.46 \pm 0.22$ & 27,020 & +530 & -500 & \\
\hline 4213 & (Favid) & $61.7-71.5$ & $4.34 \pm 0.34$ & 25,210 & +660 & -610 & \\
\hline 4214 & & $71.5-100$ & $4.66 \pm 0.36$ & 24,630 & +640 & -590 & $7.5,2.9$ \\
\hline 4315 & Bobo U17 & $44.5-53.1$ & $3.05 \pm 0.26$ & 28030 & +710 & -650 & \\
\hline 4216 & (Favid) & $53.1-63.9$ & $4.64 \pm 0.35$ & 24,670 & +640 & -590 & \\
\hline 4217 & & $63.9-100$ & $3.65 \pm 0.24$ & 26,590 & +550 & -520 & $5.1,2.4$ \\
\hline OZD-538 & & $0-100$ & $5.24 \pm 0.30$ & 23,700 & +470 & -450 & \\
\hline 9507 & Bobo U18 & $0-31.0$ & $6.09 \pm 0.25$ & 22,480 & +340 & -320 & \\
\hline 4218 & (Favid) & $45.9-60.0$ & $1.57 \pm 0.16$ & 33,340 & +880 & -800 & \\
\hline 4219 & & $60.0-83.5$ & $1.54 \pm 0.21$ & 33,530 & +1160 & -1010 & \\
\hline 4220 & & $83.5-100$ & $1.89 \pm 0.14$ & 31,880 & +600 & -560 & 0 \\
\hline OZD-544 & & $0-100$ & $1.84 \pm 0.20$ & 22,100 & +930 & -830 & \\
\hline 4221 & Bobo U20 & $49.8-63.3$ & $2.27 \pm 0.22$ & 30,410 & +810 & -740 & \\
\hline 4222 & (Favid) & $63.3-78.1$ & $2.13 \pm 0.19$ & 30,920 & +750 & -680 & \\
\hline 4223 & & $78.1-100$ & $2.06 \pm 0.17$ & 31,190 & +690 & -630 & 0 \\
\hline 4225 & Bobo U21 & $56.8-73.1$ & $3.65 \pm 0.30$ & 26,590 & +680 & -630 & \\
\hline 4226 & (Favid) & $73.1-100$ & $3.91 \pm 0.30$ & 26,050 & +640 & -590 & 1.0 \\
\hline OZD-543 & & $0-100$ & $7.08 \pm 0.32$ & 21,250 & +370 & -340 & \\
\hline 4227 & Bobo U24 & $49.5-61.3$ & $3.30 \pm 0.27$ & 27,400 & +680 & -630 & \\
\hline 4228 & (Favid) & $61.3-72.9$ & $2.92 \pm 0.25$ & 28,390 & +710 & -650 & \\
\hline 4229 & & $72.9-100$ & $3.44 \pm 0.25$ & 27,070 & +600 & -560 & 1.0 \\
\hline 9504 & Bobo U28 & $0-30.0$ & $18.2 \pm 0.62$ & 13,700 & +280 & -270 & \\
\hline
\end{tabular}


Table 1 Radiocarbon results (Continued)

\begin{tabular}{llcccccc}
\hline $\begin{array}{l}\text { Lab code }^{\mathrm{a}} \\
\text { (ANUA-) }\end{array}$ & Sample & $\begin{array}{c}\text { Dissolved } \\
\text { percent }\end{array}$ & pMC & $\begin{array}{c}{ }^{14} \mathrm{C} \text { age }^{\mathrm{b}} \\
(\mathrm{BP})\end{array}$ & $\begin{array}{c}\text { Error }^{\mathrm{c}} \\
\text { (years) }\end{array}$ & $\begin{array}{c}\text { Error }^{\mathrm{c}} \\
\text { (years) }\end{array}$ & $\begin{array}{c}\text { Calcite }^{\mathrm{d}} \\
\%\end{array}$ \\
\hline 6912 & (Favid) & $60.3-71.8$ & $4.71 \pm 0.31$ & 24,550 & +540 & -510 & \\
6913 & & $71.8-86.7$ & $4.53 \pm 0.30$ & 24,870 & +550 & -510 & \\
6914 & & $86.7-100$ & $5.34 \pm 0.35$ & 23,540 & +550 & -520 & 2.0 \\
OZD-539 & & $0-100$ & $7.91 \pm 0.62$ & 20,400 & +330 & -320 & \\
9502 & Bobo U30 & $0-29.0$ & $7.85 \pm 0.43$ & 20,440 & +450 & -430 & \\
6115 & (Favid) & $64.8-76.0$ & $4.09 \pm 0.26$ & 25,680 & +530 & -500 & \\
6114 & & $76.0-87.3$ & $4.10 \pm 0.27$ & 25,660 & +540 & -510 & \\
6113 & & $87.3-100$ & $3.70 \pm 0.24$ & 26,500 & +550 & -510 & 1.0 \\
OZD-541 & & $0-100$ & $7.75 \pm 0.27$ & 20,550 & +280 & -280 & \\
8205 & SEN(N)8 & $62.3-72.0$ & $0.48 \pm 0.09$ & 42,970 & +1680 & -1390 & \\
8206 & (Porites) & $72.0-86.9$ & $0.60 \pm 0.08$ & 41,130 & +1160 & -1010 & \\
8203 & & $86.9-100$ & $0.59 \pm 0.10$ & 41,220 & +1500 & -1260 & 1.6 \\
6822 & GBR-A & $62.5-74.4$ & $17.06 \pm 0.75$ & 14,200 & +360 & -340 & \\
6820 & (Galaxea & $74.4-86.7$ & $16.93 \pm 0.72$ & 14,270 & +350 & -340 & \\
6819 & clavus) & $86.7-100$ & $16.67 \pm 0.64$ & 14,390 & +320 & -300 & 0 \\
\hline
\end{tabular}

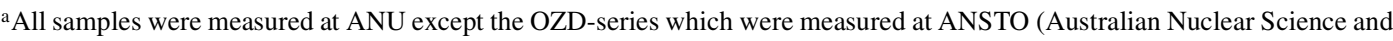
Technology Organisation).

${ }^{\mathrm{b}}$ Age obtained using Libby's half life (5568 yr).

'Errors are quoted as two sigma.

${ }^{\mathrm{d}} \mathrm{XRD}$ analyses for bulk samples. Where two entries are given, the second corresponds to wall fraction following mechanical cleaning to remove septa.

The vessel was connected by a Cajon Ultra-Torr ${ }^{\circledR}$ fitting to the main vacuum line. After $1.5 \mathrm{hr}$ of pumping and out-gassing of the acid, a vacuum of $10^{-4}$ Torr could be achieved. The vessel was then tilted to drip acid onto the sample to start the reaction. The $\mathrm{CO}_{2}$ produced was dried by passing through two spiral traps immersed in a dry ice-ethanol mixture $\left(-78.8^{\circ} \mathrm{C}\right)$, and cryogenically collected at liquid nitrogen temperature. The $\mathrm{CO}_{2}$ pressure was measured at intervals to determine the amount of sample dissolved. The dried $\mathrm{CO}_{2}$ was then transferred via one of several outlets to the graphitisation apparatus described previously. The iron powder had previously been reduced in situ with $\sim 400$ Torr $\mathrm{H}_{2}$ at $400{ }^{\circ} \mathrm{C}$ for several hours. The setup includes a cold finger to trap water vapor, and a pressure transducer to monitor the progress of the conversion reaction. The apparatus has a double valve system for isolating and removing the samples from the vacuum system. ANU sucrose was used as a standard. The sucrose was weighed and placed in a vycor tube $(6 \mathrm{~mm}$ diameter and $\sim 20 \mathrm{~cm}$ long) with $\mathrm{CuO}$ and $\mathrm{Ag}$ wire. The tube was evacuated and sealed with a torch and placed in an oven at 900 ${ }^{\circ} \mathrm{C}$ for $8-10 \mathrm{hr}$ to combust and convert the sucrose to $\mathrm{CO}_{2}$. The rest of the procedure was the same as that used for samples.

After evacuating the sample tube $\left(<10^{-4}\right.$ Torr $)$ at liquid nitrogen temperature, it was filled with approximately 2.2 times molar fraction of excess $\mathrm{H}_{2}$ relative to $\mathrm{CO}_{2}$. The valves were closed and graphitization reaction started by inserting the end of the tube into a high temperature oven at $625{ }^{\circ} \mathrm{C}$ at a separate location. Up to four sample tubes could be heated at the same time. Water vapor produced by the reaction was removed by a cold finger in a dry-ice-ethanol bath attached to the graphitization apparatus. The change in pressure due to $\mathrm{H}_{2}$ consumption was monitored with pressure transducer. Pressure readings indicated that most of the reaction had occurred during he first $0.5-1 \mathrm{hr}$, and 
was essentially complete within $3 \mathrm{hr}$. However, to ensure full conversion, the process was continued for at least $6 \mathrm{hr}$.

Graphite yields were calculated by both weighing the residue, and from the measured pressure difference, and ranged from $85 \%$ to $100 \%$. Conversion efficiency was typically greater than $95 \%$. At such high efficiencies, graphitization related carbon isotope fractionation is expected to be minimal (e.g. McNichol et al. 1992; Kitagawa et al. 1993; Brown and Southon 1997).

Background ${ }^{14} \mathrm{C}$ levels were monitored regularly using the international old calcite standard, IAEAC1 (Rozanski et al. 1992). The background values ranged from 0.04 pMC (percent modern carbon) to $0.30 \mathrm{pMC}$, and were typically $0.25 \mathrm{pMC}$, equivalent to an age of $48,000 \mathrm{yr}$. Therefore, samples as old as 40,000 yr could be reliably measured using the present system and procedures.

\section{RESULTS AND DISCUSSION}

\section{Integrity of Samples}

The basic requirement in ${ }^{14} \mathrm{C}$ and $\mathrm{U} / \mathrm{Th}$ dating is the assumption of closed system behavior for the isotopes used in the measurement. In general, two sources of contamination can be expected in ${ }^{14} \mathrm{C}$ dating. One from contamination in the laboratory, including during the graphitization process, and the other is from inherent diagenesis in corals.

The former can be assessed by using "old" carbonate, which ideally contains no ${ }^{14} \mathrm{C}$. In our laboratory, we have used Carrara marble (IAEA C-1) that yielded a range of ages from 47,000 to $50,000 \mathrm{BP}$ for the total analytical blank, including AMS analysis. Therefore, any dates younger than this age are reliable, assuming sample integrity. Numerous studies have attempted to characterize the cause and circumstances of diagenetic processes in corals (e.g. Bathurst 1968; Lighty 1985; Moore 1989; Strasser et al. 1997) however, the nature of the mechanism is still unclear (Bar-Matthews et al. 1993). To evaluate its effects in corals several criteria have previously been employed such as microscopic textural analysis, XRD measurements, stable isotope measurements, total uranium contents, the amount of ${ }^{232} \mathrm{Th}$ in the coral, trace element analysis, and measurement of the initial ${ }^{234} \mathrm{U} /{ }^{238} \mathrm{U}$ ratio $\delta^{234} \mathrm{U}(\mathrm{T})$.

\section{Textural Investigation and XRD Analysis}

Evaluating the possibility of open system behavior for ${ }^{14} \mathrm{C}$ is much more difficult than for Th and $\mathrm{U}$ isotopes. However, to some extent, it is possible to check for secondary material, as pristine coral consists only of aragonite. XRD can be used to check for secondary calcite. We have investigated textures with a petrographic microscope and XRD analyses. In most of the samples, secondary fillings were observed in the voids of the coral. These were mechanically removed using a dental drill prior to leaching. Thus, even in cases where minor secondary replacement was observed, and detected in XRD analyses of whole samples, they were removed. All the samples had typically less than $2 \%$ calcite, which is within the uncertainty of detection limits (Table 1).

\section{Stable Isotope Analysis}

For each sample, stable isotopes of oxygen and carbon were measured. If marine carbonates preserve their original composition, both isotopes values should be around zero. Stein et al. (1993) conducted an extensive study of Huon LIG corals. Oxygen isotopes are likely to have been affected if exotic isotopes were introduced into the coral skeleton through percolation of meteoric water. However, oxygen and carbon isotopes appear not to have responded to small-scale diagenetic alteration 
in corals. The present corals are significantly younger than LIG corals used by Stein et al. (1993), and as such they are less likely to have detectable variations in oxygen or carbon isotopes correlated with small scale diagenesis. The test results showed that carbon and oxygen isotope values were within acceptable ranges as found by Stein et al. (1993).

\section{Uranium Concentration}

Uranium concentration of corals in this study range between $\sim 2$ and $3.5 \mathrm{ppm}$. These values are consistent with previously reported results for younger age corals (Hamelin et al. 1991), Holocene corals (Edwards et al. 1988; Zhu et al. 1993), and the LIG corals (Edwards et al. 1986; Hamelin et al. 1991; Edwards et al. 1987; Stirling et al. 1995, 1998). Species dependence of uranium content in corals has been reported previously (Zhu et al. 1993; Stirling 1995). Stirling (1995) reported that uranium content of Acropora was higher than other species such as Porites or Favidae, but Zhu et al. (1993), pointed out that Acropora and Montipora corals have inherently higher ${ }^{238} \mathrm{U}$ values in Holocene corals. Therefore, the variations in Uranium content might be species dependent, but generally range from 2 to $4 \mathrm{ppm}$. All corals used in the present study are well within this range.

\section{${ }^{232}$ Th Concentration in the Corals}

${ }^{232} \mathrm{Th}$ in modern corals is typically less than $0.5 \mathrm{ppb}$ (Edwards et al. 1986; Chen et al. 1991). In the freshwater or marine environment, voids can be filled with externally introduced detritus material. Therefore, if ${ }^{232} \mathrm{Th}$ abundance departs significantly from the $0.5 \mathrm{ppb}$ limit, it may indicate the presence of secondary contamination. Previous researchers have attempted to correct for excess levels of ${ }^{232} \mathrm{Th}$, although the correction is not generally considered to be reliable (e.g. Chen, et al. 1991). The effect is to shift the measured Th-U age toward younger ages.

In the present study, for most corals, ${ }^{232} \mathrm{Th}$ is well below the $0.5 \mathrm{ppb}$ limit. One coral has $\approx 1.1 \mathrm{ppb}$. This coral was collected at a depth of $-175 \mathrm{~m}$ in the Great Barrier Reef (Veeh and Veevers 1970). It had not been exposed to aerial or subaerial environment. Therefore, the excess ${ }^{232} \mathrm{Th}$ must have been added in the marine environment. There are no discernable systematic correlations between ${ }^{232} \mathrm{Th}$ and $\mathrm{U} / \mathrm{Th}$ age, $\delta^{234} \mathrm{U}(\mathrm{T})$, or $\Delta^{14} \mathrm{C}$.

$\delta^{234} U(T)$

Behavior of trace chemical elements with degree of diagenesis was studied in Caribbean corals by Bar-Matthews et al. (1993). These authors investigated both textural structures with an optical microscope and a scanning electron microscope, and then conducted chemical analyses. They concluded that textural analysis is necessary, yet it is not a quantitative or reliable test in evaluating the degree of diagenesis. Most of the alteration was observed in the voids of corals as secondary filling and calcium carbonate deposition. However, cementation in these corals was not always by calcite, but in many cases through secondary aragonite (Bar-Matthews et al. 1993). Therefore, they were presumably altered in the marine environment, quite likely at the intertidal or supertidal zone as indicated by other studies (e.g. Bar-Mathews et al. 1993; Lighty 1985).

Many studies have detailed the shift in $\delta^{234} \mathrm{U}(\mathrm{T})$ through diagenesis (Edwards 1988; Ku et al. 1990; Banner et al. 1991; Bard et al. 1991; Chen et al. 1991; Stein et al. 1993; Gallup et al. 1994; Stirling et al. 1995, 1998). The magnitude of $\delta^{234} \mathrm{U}(\mathrm{T})$ tends to be elevated as the degree of diagenesis increases. Gallup et al. (1994) demonstrated this trend for corals from Barbados and the Bahamas. Also, Stirling (1998) observed a similar increase in $\delta^{234} \mathrm{U}(\mathrm{T})$ with age for corals from Western Australia. We have used a similar acceptance criterion: $\delta^{234} \mathrm{U}(\mathrm{T})=149 \pm 10 \%$ as used in previous studies (e.g. Stirling et al. 1998). 


\section{Radiocarbon and Th-U Dating of Corals from Huon Peninsula}

Veracity of the results from ${ }^{14} \mathrm{C}$ and Th-U dating of corals ultimately depend on the quality of the samples. This is a vexing issue that cannot be resolved with complete certainty, but relies on a battery of tests, each of which provide, at best, circumstantial evidence for or against. We have employed a quantitative test of ${ }^{14} \mathrm{C}$ dates that relies on progressive dissolution of coral samples. We have determined empirically that the first $50 \%$ of a leached coral sample is more likely to have been contaminated by extraneous, younger age carbon, than the last 50\% (Burr et al. 1993). We have adopted a procedure whereby the first $50 \%$ of a sample was selectively dissolved and discarded. The remainder was dissolved in at least three steps and each aliquot was ${ }^{14} \mathrm{C}$-AMS dated. This procedure was applied to each dated sample. The data for all of the samples can be found in Figure 2 and Table 1. In every case, within twice the statistical uncertainty, the last three aliquots have identical ${ }^{14} \mathrm{C}$ ages. Samples included in the discussion below pass all of these tests within limits of assigned errors. A major concern with ${ }^{14} \mathrm{C}$ dates for samples older than $30 \mathrm{ka}$ is the possibility of contamination with younger age or modern carbon. There is no absolute a priori test to determine the issue. In particular, for the $52 \mathrm{ka}$ samples reported below, the ${ }^{14} \mathrm{C}$ ages range from 35 to $45 \mathrm{ka} \mathrm{BP}$ and may need to be viewed with some caution. However, we consider that the selective dissolution test is the best quantitative indicator that can be devised at present.

We tested the effectiveness of this procedure by using corals as old as $120,000 \mathrm{yr}$ that grew during the Last Interglacial (LIG). Burr et al. (1992), conducted step-wise dissolution of a reef IV coral, from Huon Peninsula, which was previously dated $(72.8 \pm 2.2 \mathrm{ka}$; Chappell et al. 1996). The first $40 \%$ of this coral was contaminated by younger carbon; the next $60 \%$ gave an age close to the analytical background. We have used a LIG coral from Western Australia (WA-1) that was previously Th-U dated (Stirling et al. 1995) and has an age of $124.7 \pm 0.9 \mathrm{ka}$ with an initial $\delta^{234} \mathrm{U}(\mathrm{T})$ ratio of $152 \pm 2$. WA- 1 appears to be pristine under the optical microscope, and no calcite was detected by XRD analysis. The first 0-17\% aliquot from WA-1 shows a considerably younger ${ }^{14} \mathrm{C}$ age compared to the analytical background ( 48,000 BP). However, the next 5 aliquots, indicate an almost uniform age of around 49,000 BP. Two other LI corals from Western Australia were treated similarly and radiocarbon dated. For the first coral, the ( $0 \%$ to $54 \%$ ) aliquot gave an age of $35,270 \pm 1490 \mathrm{BP}$. The remainder of the sample (54\% to $100 \%$ ) was dated at 47,690 $\pm 1500 \mathrm{BP}$. The second coral was dissolved in three steps (15\% to $28 \%, 28 \%$ to $36 \%$, and $55 \%$ to $100 \%$ ) and yielded the corresponding ages of 40,960 BP, 42,560 BP, and 50,770 BP, respectively.

Giant clams, Tridacna gigas do not incorporate $\mathrm{U}$ in their aragonite skeleton and cannot be dated by U-series methods. Tridacna were previously collected from Huon terraces IIIa and IIIb from locations of known age. The harder skeleton of Tridacna may be expected to be resistant to alteration compared to fossil corals and therefore provide more reliable ${ }^{14} \mathrm{C}$ ages. However, the estimated age of available Tridacna samples in the collection was over $50,000 \mathrm{yr}$. We ${ }^{14} \mathrm{C}$ dated two samples. A Tridacna from reef IIIa shows a nearly constant age profile at $\sim 47,000 \mathrm{BP}$ which is close to the analytical background of the present system. Another Tridacna was treated in a similar fashion. The first $17 \%$ indicated younger carbon contamination. However the last $~ 50 \%$ yielded consistent results of 47,000 BP. Both Tridacna consist of $100 \%$ aragonite as determined by XRD analysis. It appears that the harder skeleton of Tridacna is also susceptible to alteration in the outer layers.

Most of the samples used in the present study have also been measured at another laboratory. Samples were sent to ANSTO (Australian Nuclear Science and Technology Organization) for ${ }^{14} \mathrm{C}$ dating (Hotchkis et al. 1996). Measurements of ${ }^{14} \mathrm{C}$ at ANSTO were on whole coral samples, without selective dissolution. This is shown as the (0-100\%) fully dissolved fraction in Figure 2. As can be seen, 
Figure 2a All the samples used in the present study were subjected to step-wise dissolution as shown in these examples. The fraction of dissolved coral was determined from pressure and temperature measurements of evolved $\mathrm{CO}_{2}$ in a calibrated volume. The hatched columns $(0-$ $100 \%)$ show the results of bulk analysis for a different piece of the same coral.
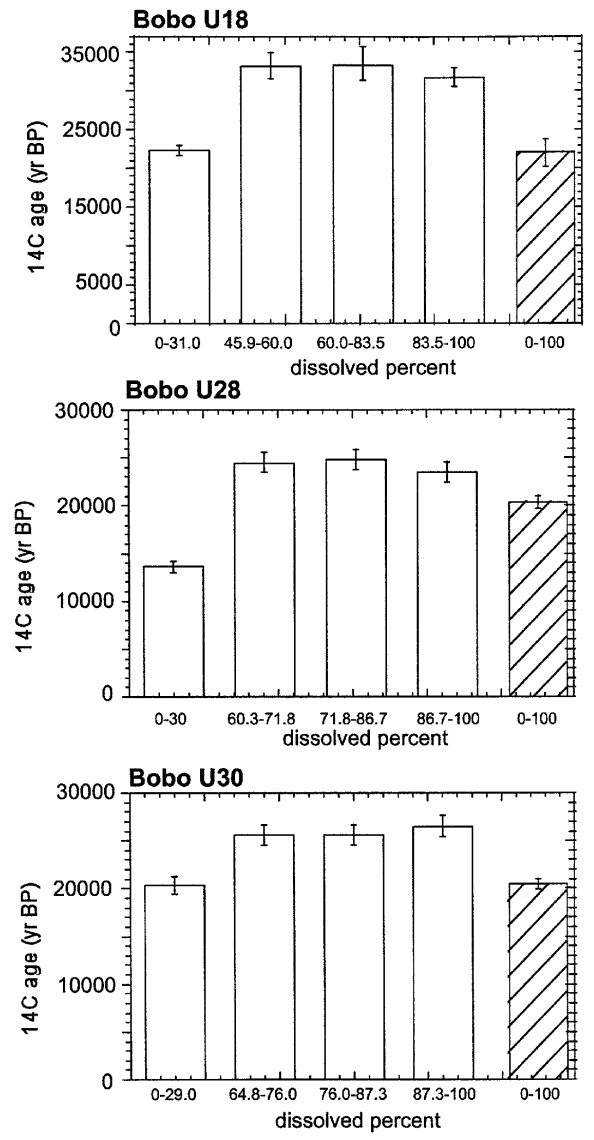

all of the dates measured at ANSTO are significantly younger than those for partially dissolved samples. This, and the discussion in previous sections, clearly indicate the importance of step-wise dissolution.

In summary, the above experiments illustrate the following points: First, the necessity of strict criteria based on textural analysis, XRD and step-wise dissolution. Second, that approximately the first $20 \%$ of dissolved samples are likely to be contaminated by younger carbon. And third, that after $50 \%$ dissolution, most of the contamination is eliminated.

Overall, tests using step-wise dissolution appear to be the only way to ascertain the veracity of ${ }^{14} \mathrm{C}$ ages of corals. Our results are consistent with the experiments of Burr et al. (1993) that after 50\% etching, ${ }^{14} \mathrm{C}$ age approaches analytical background levels. The criteria we have applied to each sample requires ${ }^{14} \mathrm{C}$ dating of at least three aliquots, after the first $50 \%$ of the sample is selectively dissolved and discarded. The results were considered acceptable if the three dates agreed within analytical uncertainties. Although, this appears to be the best quantitative method available so far, it does not guarantee that samples are fully free of diagenesis at a level not to affect age determinations.

The new data comprise of 25 new TIMS Th-U dates and over 200 AMS available dates (Table 2). The ${ }^{14} \mathrm{C}$ ages and Th-U calendar ages are shown in Figure 3 together with data from other studies. Sample age was calculated from the weighted mean of three available ages measured following $50 \%$ 

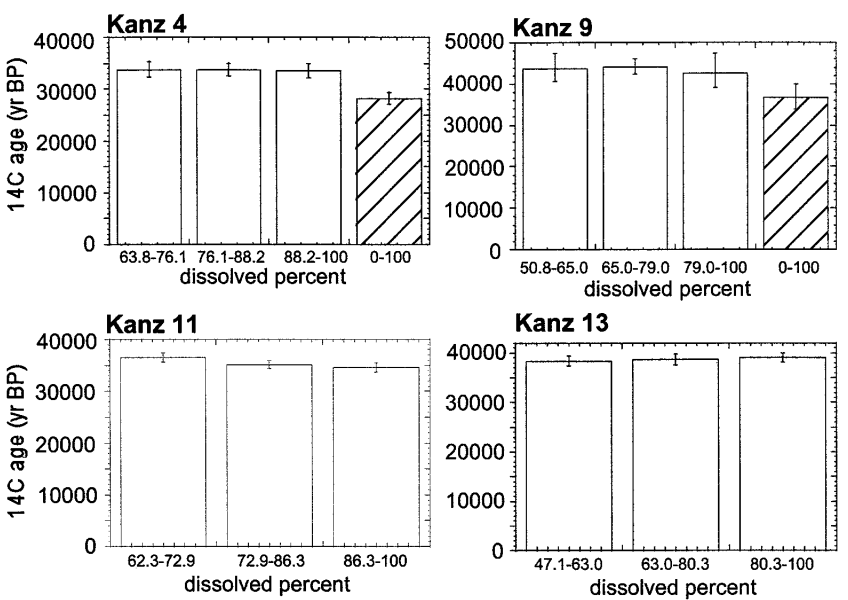

Kanz 13
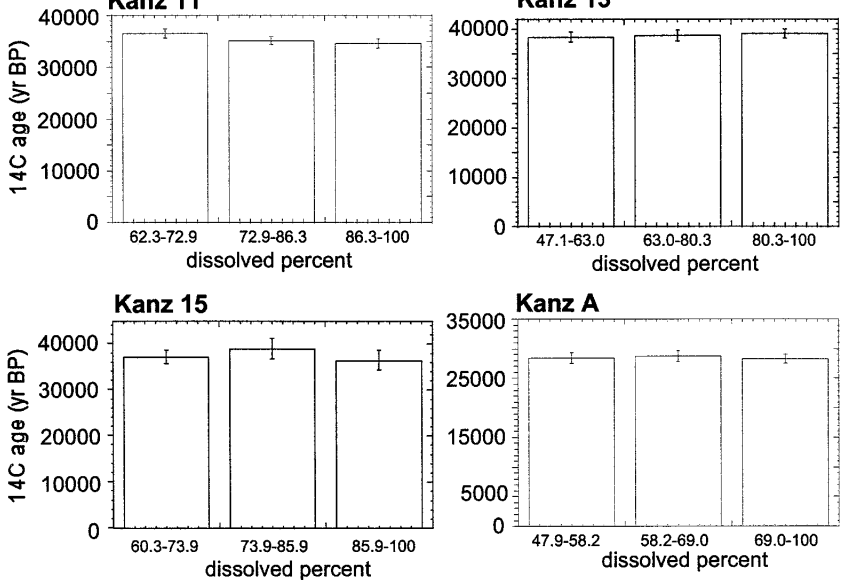

Figure 2b Same as Figure 2a but for different corals
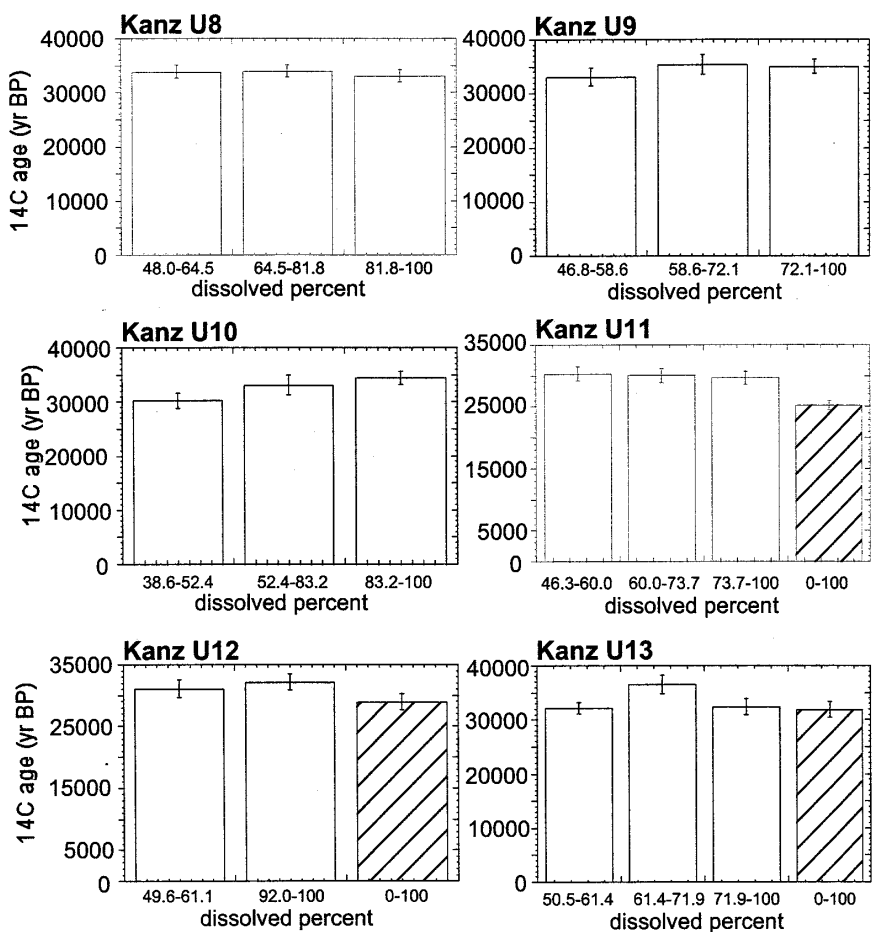

Figure 2c Same as Figure 2a but for different corals 
Table $2 \mathrm{U} / \mathrm{Th}$ and ${ }^{14} \mathrm{C}$ results

\begin{tabular}{|c|c|c|c|c|c|}
\hline Sample $^{\mathrm{a}}$ & $\begin{array}{c}\text { U/Th age } \\
\text { (ka cal BP) }\end{array}$ & $\begin{array}{c}{ }^{14} \mathrm{C} \text { age } \\
(\mathrm{ka} \mathrm{BP})^{\mathrm{b}}\end{array}$ & $\begin{array}{l}\Delta^{14} \mathrm{C} \\
(\% o)^{\mathrm{c}}\end{array}$ & Reef $^{d}$ & $\begin{array}{c}\text { Sea-levels } \\
\text { and height }(\mathrm{m})^{\mathrm{e}}\end{array}$ \\
\hline \multicolumn{6}{|l|}{ Kanzarua } \\
\hline Kanz 4 & $51.5 \pm 1.6$ & $33.6 \pm 0.4$ & 6678 & IIIa & $-58(86)$ \\
\hline $\operatorname{Kanz} 4^{\alpha}$ & $51.2 \pm 0.8$ & & & & \\
\hline Kanz 9 & $53.4 \pm 0.3$ & $43.9 \pm 0.8$ & 1759 & IIIa & $-72(78)$ \\
\hline $\operatorname{Kanz} 9^{\mathrm{T}}$ & $54.6 \pm 0.7$ & & & & \\
\hline Kanz $11^{p}$ & $51.3 \pm 0.3$ & $35.4 \pm 0.3$ & 5063 & IIIa & $-65(78)$ \\
\hline Kanz 13p & $38.3 \pm 0.5$ & $38.9 \pm 0.3$ & -187 & $\mathrm{IIIb}$ & $-59(48)$ \\
\hline Kanz $15^{p}$ & $42.0 \pm 0.6$ & $37.5 \pm 0.6$ & 511 & IIIc & $-79(39)$ \\
\hline Kanz U8p & $37.0 \pm 0.6$ & $33.6 \pm 0.4$ & 333 & IIa & $-77(27)$ \\
\hline Kanz U9 & $42.3 \pm 0.2$ & $34.7 \pm 0.5$ & 1075 & IIa & $-91(28)$ \\
\hline Kanz U9 ${ }^{\alpha}$ & $41.8 \pm 0.6$ & & & & \\
\hline Kanz U9 & $42.2 \pm 0.3$ & & & & \\
\hline Kanz U10p & $43.7 \pm 0.3$ & $33.2 \pm 0.5$ & 2162 & IIIc & $-73(49)$ \\
\hline Kanz U11 & $37.9 \pm 0.3$ & $30.0 \pm 0.3$ & 1351 & IIa & $-79(27)$ \\
\hline Kanz U12 & $37.5 \pm 0.7$ & $31.7 \pm 0.5$ & 794 & IIa & $-79(26)$ \\
\hline Kanz U13 & $35.8 \pm 0.4$ & $33.8 \pm 0.5$ & 139 & IIa & $-74(26)$ \\
\hline Kanz U14 & $34.8 \pm 0.8$ & $37.4 \pm 0.4$ & -360 & IIa & $-72(26)$ \\
\hline Kanz U15 & $33.4 \pm 0.2$ & $36.7 \pm 0.3$ & -409 & II & $-71(23)$ \\
\hline Kanz U16p & $30.4 \pm 0.4$ & $31.8 \pm 0.3$ & -249 & II & $-56(29)$ \\
\hline Kanz A & $37.5 \pm 0.2$ & $28.5 \pm 0.3$ & 1696 & II & $-80(25)$ \\
\hline \multicolumn{6}{|l|}{ Bobongara } \\
\hline Bobo U10 & $37.2 \pm 0.2$ & $31.7 \pm 0.4$ & 731 & IIa & $-74(49)$ \\
\hline Bobo U11 & $37.9 \pm 0.3$ & $26.0 \pm 0.3$ & 2820 & IIa & $-76(49)$ \\
\hline Bobo U17 & $32.0 \pm 0.2$ & $26.6 \pm 0.4$ & 741 & IIc & $-86(20)$ \\
\hline Bobo U18 & $42.4 \pm 0.2$ & $32.7 \pm 0.5$ & 1897 & IIb & $-103(37)$ \\
\hline Bobo U20 & $37.6 \pm 0.2$ & $30.9 \pm 0.4$ & 1023 & $\mathrm{IIb}$ & $-84(40)$ \\
\hline Bobo U21 & $29.7 \pm 0.2$ & $26.3 \pm 0.5$ & 373 & IIc & $-68(30)$ \\
\hline Bobo U21 ${ }^{\alpha}$ & $33.4 \pm 0.6$ & & & & \\
\hline Bobo U24 & $32.2 \pm 0.2$ & $27.6 \pm 0.4$ & 583 & IIc & $-76(30)$ \\
\hline Bobo U24 ${ }^{\alpha}$ & $33.0 \pm 0.5$ & & & & \\
\hline Bobo U28 & $32.3 \pm 0.5$ & $24.4 \pm 0.3$ & 1388 & IIc & $-85(22)$ \\
\hline Bobo U30 & $31.5 \pm 0.2$ & $26.0 \pm 0.3$ & 791 & IIc & $-77(27)$ \\
\hline \multicolumn{6}{|l|}{ Others } \\
\hline SEN(N) $8^{p}$ & $52.4 \pm 1.3$ & $41.7 \pm 0.8$ & 2172 & IIIc & $\mathrm{nA}$ \\
\hline GBR-A & $17.0 \pm 0.1$ & $14.3 \pm 0.2$ & 315 & & \\
\hline GBR-A ${ }^{\alpha}$ & $17.0 \pm 1.0$ & & & & $(-175)$ \\
\hline
\end{tabular}

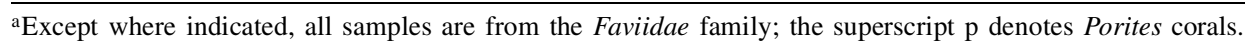
Analyses on Faviidae corals are for the wall fractions only. The superscript $\alpha$ and $\mathrm{T}$ indicate previously reported values using $\alpha$-counting and TIMS measurements, respectively (Chappell et al. 1996).

${ }^{b}$ Using Libby's half-life ( $5568 \mathrm{yr}$ ). The ${ }^{14} \mathrm{C}$-age is the weighted mean of ages from aliquots corresponding to the final $50 \%$ of coral mass selectively dissolved in at least three steps (Table 1).

${ }^{\mathrm{c}}$ The $\Delta^{14} \mathrm{C}$ value is the per mil difference between the initial ${ }^{14} \mathrm{C} /{ }^{12} \mathrm{C}$ of a sample (normalized for isotopic fractionation) and the ${ }^{14} \mathrm{C} /{ }^{12} \mathrm{C}$ of a standard; the standard has a value similar to the initial ${ }^{14} \mathrm{C} /{ }^{12} \mathrm{C}$ ration of 19 th century wood. The $\Delta{ }^{14} \mathrm{C}$ is defined and discussed in (Stuiver and Polach 1977) and equals $\left(F e^{\lambda \mathrm{T}}-1\right) \times 1000$ per mil, where $F$ is the fraction modern (Donahue et al. 1990), $\lambda$ is the decay constant that corresponds to the 5730 year half-life, and $T$ is the age in cal BP. In the present study, $\Delta{ }^{14} \mathrm{C}$ is calculated using the measured initial ${ }^{14} \mathrm{C} /{ }^{12} \mathrm{C}$ ratio and the ${ }^{230} \mathrm{Th}$ age. Quoted errors include errors in the measured ${ }^{14} \mathrm{C} /{ }^{12} \mathrm{C}$ ratio and ${ }^{230} \mathrm{Th}$ age.

${ }^{\mathrm{d}}$ Reef numbering is described in (Ota et al. 1992; Chappell et al. 1996).

${ }^{\text {eS}}$ Sea-levels obtained using both the height of corals as shown in brackets and uplift rates for both Kanzarua (2.8 $\mathrm{m} / \mathrm{ka}$ ) and Bobongara (3.3m/ka) reported by (Chappell et al. 1996). 
dissolution. The weighted average is within twice the experimental error of individual measurements. Results from one coral from the Great Barrier Reef, originally dated by Veeh and Veevers (1970) with conventional ${ }^{14} \mathrm{C}$ and Th-U $(13,600-13,860 \pm 0.220 \mathrm{ka} \mathrm{BP}$ and $17,000 \pm 1000 \mathrm{ka}$, respectively), are in good agreement with present results $(14,390 \pm 0.150 \mathrm{ka} \mathrm{BP}$ and $16,981 \pm 0.112$ ka). This sample is well within the field of other data of similar age (Figure 3). All of the other corals are from the uplifted Huon Peninsula coral terraces of Papua New Guinea collected during the 1992 international expedition (Ota et al. 1994). Four samples were previously Th-U dated using TIMS and five others by $\alpha$-spectrometry (Chappell et al. 1996); they are included with the new results. The previous data have larger analytical uncertainties (Omura et al. 1995; Chappell et al. 1996), however, they are in good agreement with the new TIMS data.

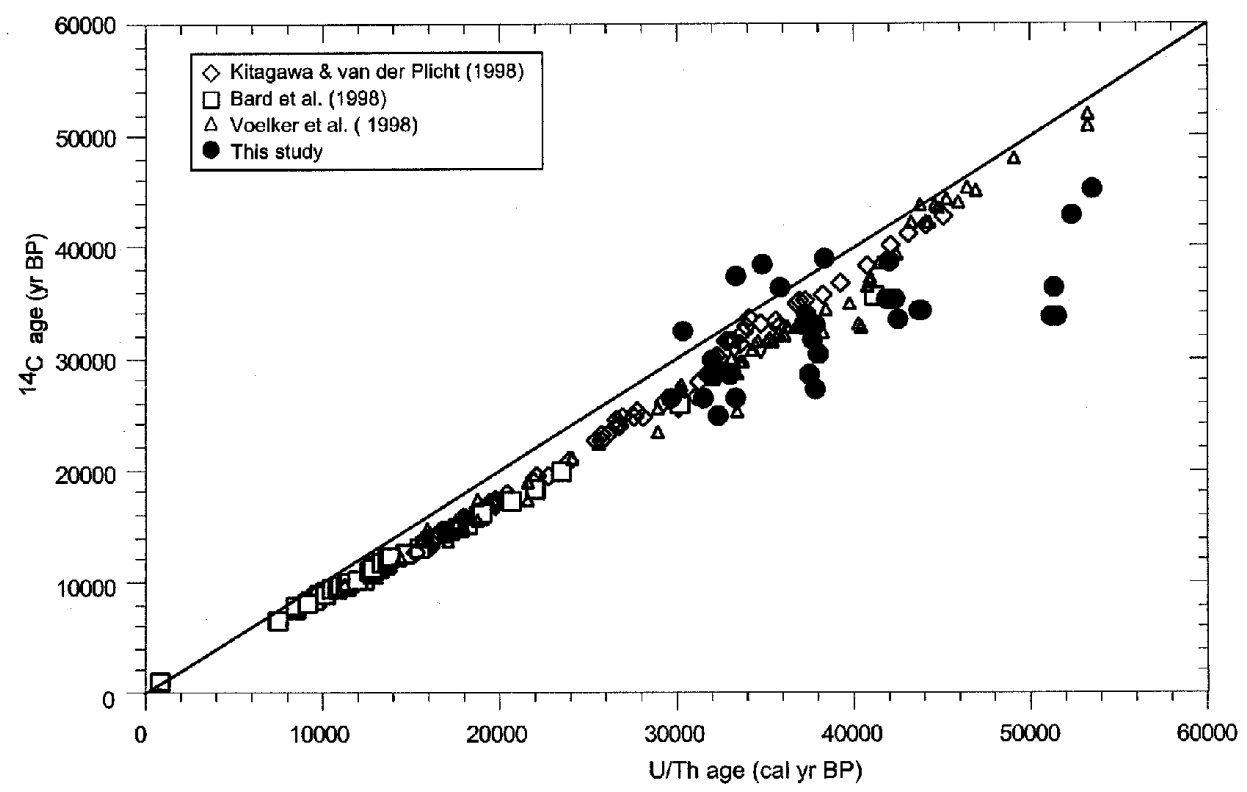

Figure 3 The present coral ${ }^{14} \mathrm{C}$ and $\mathrm{U}$-series ages, and previously published data. The baseline of younger ${ }^{14} \mathrm{C}$ ages appear to be consistent in all the data sets. The present data show four distinct peaks of ${ }^{14} \mathrm{C}$ excess. In between these peaks some ${ }^{14} \mathrm{C}$ ages appear to be older than the corresponding calendar ages.

The measured Th-U ages of corals, from the uplifted Huon Peninsula Reefs II and III (Chappell 1974; Chappell et al. 1996), range between $29 \mathrm{ka}$ and $55 \mathrm{ka}$. Several trends are apparent in the data; first, there is a noticeable increase in the divergence of the ${ }^{14} \mathrm{C}$ ages from calendar dates, from $30 \mathrm{ka}$ to $50 \mathrm{ka}$, that follows the same trend as the bulk of the previous data; second, there are significant, $1000 \%$ to $7000 \%$ (equivalent to age shifts of $7 \mathrm{ka}$ up to $17 \mathrm{ka}$ ) $\Delta^{14} \mathrm{C}$ excursions at periods that correspond to particular reef-building episodes and sea-level rises at Huon Peninsula; and third, some ${ }^{14} \mathrm{C}$ ages in between the "peaks" are older than corresponding calendar ages.

That the Th-U ages cluster at particular times is no surprise as we are specifically dating corals from discrete reef sections; we do not have a continuous record of coral growth over this time period. However, the magnitude of the ${ }^{14} \mathrm{C}$ age excursions from calendar ages is unprecedented. The present data are shown on an expanded scale in Figure 4. It is clear that data with ${ }^{14} \mathrm{C}$ ages older than calendar ages 
are distributed in-between the peaks. Two previous coral data points are within the range of present ages; one is a 30,200 yr old coral from Barbados, and the other a 42,000 yr old coral from Huon (Bard et al. 1993, 1998; Figure 3). Both of these overlap with the baseline defined by the present measurements (Figure 3). At tectonically uplifting sites, coral terraces grow when sea-level rise overtakes uplift. The uplift rate along the Huon coast is variable but typically in the order of $3 \mathrm{~m}$ per $1000 \mathrm{yr}$ and the sea-level history has been derived previously (Chappell et al. 1996). The coincidence between sealevel rises and large excursions in ${ }^{14} \mathrm{C}$ is, at first sight, puzzling. However, we believe that these events can be directly linked to rapid global climate changes, in particular, in the North Atlantic, and are also connected with Heinrich Events and periodic re-organizations of the North Atlantic thermohaline circulation.

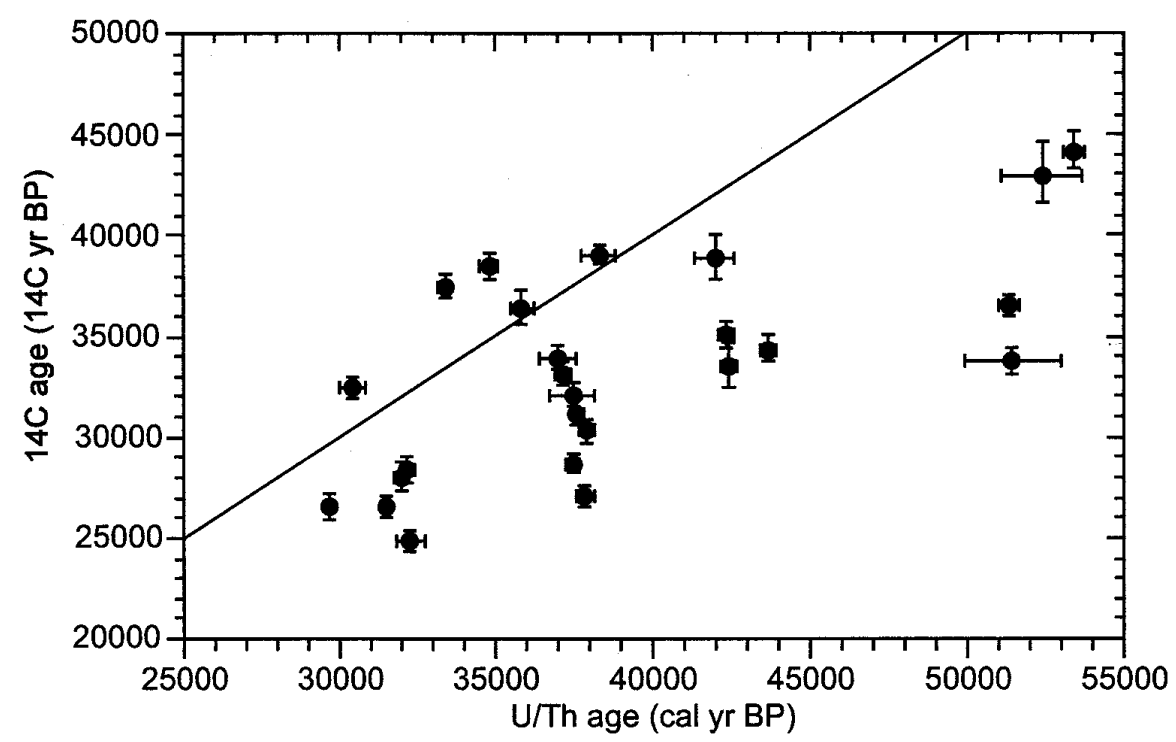

Figure $4{ }^{14} \mathrm{C}$ and $\mathrm{Th}-\mathrm{U}$ ages plotted in an expanded scale diagram. Errors are $2 \sigma$ mean. Four peaks of excess ${ }^{14} \mathrm{C}$ are clearly evident. There is no trend of increasing ${ }^{14} \mathrm{C}$ excess with age as the $\approx 37 \mathrm{ka}$ peak is larger than the $\approx 43 \mathrm{ka}$ peak. This, and other, detailed arguments based on tests of closed system behavior argue against an interpretation based on contamination by younger age or modern carbon as an explanation for the observed peaks.

There are large variations in the reported calendar ages of various Heinrich Events (Andrew 1998). This arises, in part, from mishandling of ${ }^{14} \mathrm{C}$ to calendar age conversions. Some ${ }^{14} \mathrm{C}$ ages are not even calibrated, but reported as absolute ages. Secondly, as the present data shows, the variability in ${ }^{14} \mathrm{C}$ ages may be due to rapid variations in atmospheric ${ }^{14} \mathrm{C}$. We consider that data obtained by Bond et al. (1993) on the abundance of Neogloboquadrina pachydermas from the North Atlantic core V23-81 to represent one of the best examples of the timing and signature of Heinrich Events. The ${ }^{14} \mathrm{C}$ scale of this data set was converted to calendar ages using the prescription given by Bard et al. (1998). The results are shown in Figure 5 from a paper by Lund and Mix (1998). Inspection of Figure 5 shows that the ${ }^{14} \mathrm{C}$ peaks in the calibration curve match almost exactly with the timing of minima in the foraminiferal abundance and Heinrich Events. The $32 \mathrm{ka}$ (calendar age) ${ }^{14} \mathrm{C}$ peak matches with $\mathrm{H} 3$. The 37.5 ka ${ }^{14} \mathrm{C}$ peak matches with the sharp cold stadial at $37.5 \mathrm{ka}$ which is not marked as a Heinrich Event, but appears to belong to the same class. The $42.3 \mathrm{ka}{ }^{14} \mathrm{C}$ peak matches with $\mathrm{H} 4$ at $\approx 42 \mathrm{ka}$, and the 
$52 \mathrm{ka}{ }^{14} \mathrm{C}$ peak matches with $\mathrm{H} 5$ at $52 \mathrm{ka}$. This correspondence is remarkable and is highly unlikely to be coincidental.

The important point is that the Huon Peninsula terraces, which represent episodes of sea-level rise, appear to have been built as a direct consequence of large-scale discharges of icebergs into the North Atlantic and the associated sea-level rise. The present data assert that, concurrent with each episode, there was a huge rise in atmospheric ${ }^{14} \mathrm{C}$. The ${ }^{14} \mathrm{C}$ excess, $\Delta{ }^{14} \mathrm{C}$, is shown in Figure 5. The theoretical maximum ${ }^{14} \mathrm{C}$ excess in the atmosphere, if all the sinks are cut off, is $5870 \%$ (Siegenthaler et al. 1980) and 200\% excess levels can be reached within a few hundred years. It appears that the present data provide direct evidence for the slow-down or shut-down of the North Atlantic thermohaline circulation as expounded by Broecker $(1997,1998)$. Furthermore, it solves a puzzle, again put forward by Broecker (1998):

Currently, $\approx 80 \%$ of the ${ }^{14} \mathrm{C}$ atoms required to replace those undergoing decay in the deep sea enter via the Atlantic's conveyor circulation. Hence, if this route were to be shut down during the course of the 1200calendar-year duration of the Younger Dryas, an enormous offset in the ${ }^{14} \mathrm{C}$ timescale might be expected.

A few ${ }^{14} \mathrm{C}$ ages, older than calendar ages, appear between the large ${ }^{14} \mathrm{C}$ excursions. Presumably, they correspond to the resumption of the thermohaline circulation and transport of ${ }^{14} \mathrm{C}$ to the deep ocean, initially at a rate greater than present. There is theoretical support for such age reversals in the calculations by Stocker and Wright (1998), when surface reservoir ages increase rapidly at the time of the commencement of the circulation. Interruption of the thermohaline circulation may be expected to redirect the northward movement of warm equatorial waters in the Atlantic to the Southern Ocean. Coupled with 5-10 m sea-level rise from North Atlantic icebergs, the Antarctic ice sheet may also be destabilized. The possibility that fresh water injection into Antarctic waters may interrupt the Antarctic deep-water formation has not been assessed in detail. However, Clark et al. (1996) consider a contribution to the melt-water-pulse-1A from the Antarctic ice sheet is most likely.

The $37 \mathrm{ka}$ peak in the present data and the nominal $37 \mathrm{ka}$ peaks in ${ }^{10} \mathrm{Be}$ and ${ }^{36} \mathrm{Cl}$ polar and deep-sea records, at first sight, appear to be generic. However, there is considerable uncertainty in the calendar age of the ${ }^{10} \mathrm{Be} /{ }^{36} \mathrm{Cl}$ peak. Various studies place this peak anywhere from $37 \mathrm{ka}$ to $42 \mathrm{ka}$ (Aldahan and Possnert 1998). It corresponds to a relatively long period when the geomagnetic field was low. Similarly the ${ }^{10} \mathrm{Be}$ peak is broad $(\approx 3000 \mathrm{yr})$. Whether the $37 \mathrm{ka}$ peak in the present data is the same as the ${ }^{10} \mathrm{Be}$ and ${ }^{36} \mathrm{Cl}$ peaks remains an open question.

Large $\Delta^{14} \mathrm{C}$ peaks have been observed by Kitagawa and van der Plicht (1998) at $32-33 \mathrm{ka}\left(\Delta^{14} \mathrm{C}\right.$ up to $850 \%$ o), by Voelker et al. (1998) at $33 \mathrm{ka}\left(\Delta^{14} \mathrm{C} \approx 700 \%\right.$ ) and $39 \mathrm{ka}\left(\Delta^{14} \mathrm{C} \approx 1200 \%\right.$ ), and by Bard (1998) at $41 \mathrm{ka}\left(\Delta^{14} \mathrm{C} \approx 700 \%\right.$ o). Given the uncertainties in exact timing of these events, they could be related to the ${ }^{14} \mathrm{C}$-excesses found in the present work. The magnitude of present $\Delta{ }^{14} \mathrm{C}$ range from $1000 \%$ to $2000 \%$ o to $7000 \%$. These values are within a factor of two to three of the previously determined highs. The difference between calendar and ${ }^{14} \mathrm{C}$ ages of the $51.5 \mathrm{ka}$ peak is $17.8 \mathrm{ka}$. Due to the old calendar age of this and similar samples, they could have been highly susceptible to small amounts of contamination assuming the "true" ${ }^{14} \mathrm{C}$ ages were closer to $50 \mathrm{ka}$. However, a recent study by Schramm et al. (2000) of Lake Lisan sediments has identified a similar peak, U-Th dated at $51.2 \mathrm{ka}$ with an age difference of greater then $9 \mathrm{ka}$, which tends to support the present findings. 


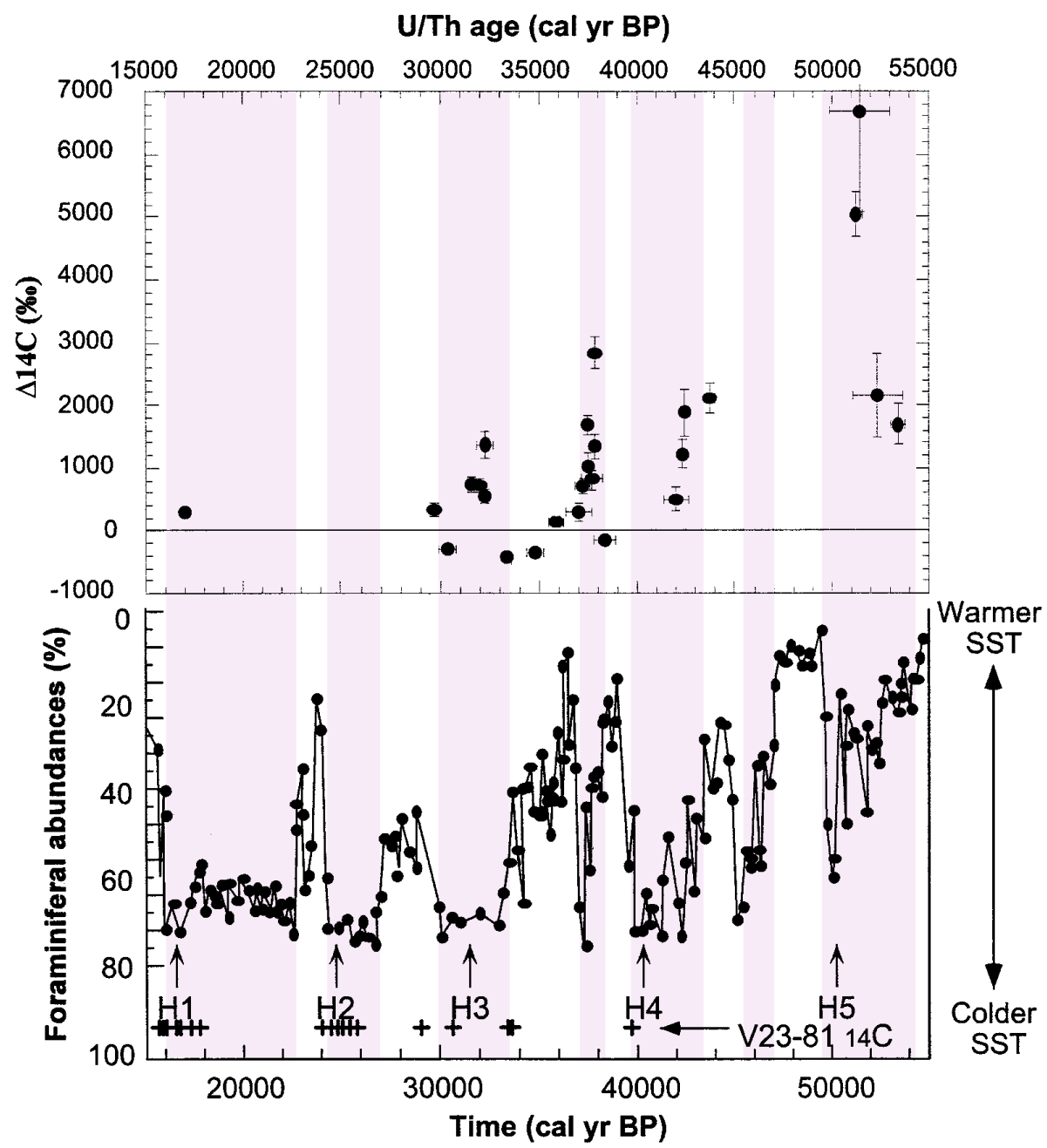

Figure 5 The upper panel shows the results from the present study. The lower panel is from the North Atlantic deep-sea core V23-81 showing systematic fluctuations in the abundance of $N$. pachyderma (s) correlated with the timing of Heinrich Events and cold stadials (Lund and Mix 1998). The time scale was derived from ${ }^{14} \mathrm{C}$ data using the calibration recommended by Bard et al. (1993). Between $\mathrm{H} 3$ and H4, a brief duration sharp peak corresponds to an excess ${ }^{14} \mathrm{C}$ peak found in the present data at $37.5 \mathrm{ka}$. This peak is not labeled as an Heinrich Event but appears to belong to the same class. Heinrich Events H3, H4, and H5 correlate with peaks of ${ }^{14} \mathrm{C}$. Such a correlation is unlikely to be coincidental and implies a genetic relationship between Heinrich Events, pulses of excess atmospheric ${ }^{14} \mathrm{C}$, sea-level rise and episodes of reef construction at Huon Peninsula. We surmise that the connecting factor between these events is the interruption of the North Atlantic Thermohaline circulation following periodic partial disruptions of the Laurentide ice-sheet.

\section{CONCLUSION}

More than 250 AMS ${ }^{14} \mathrm{C}$ dates and 25 high-precision TIMS U-series ages have been determined for 30,000-50,000-yr-old corals from the uplifted terraces of Huon Peninsula in Papua New Guinea. Previously extensive efforts to define a ${ }^{14} \mathrm{C}$ calibration curve for the period beyond around 12,000 yr, through directly measured calendar ages, only yielded a few scattered points. A new $\mathrm{CO}_{2}$ extraction and graphatization line was constructed and used for processing "old" carbonate samples only. ${ }^{14} \mathrm{C}$ 
dates of samples older than 20,000 yr may be affected by secondary younger carbon contamination. For this reason, each coral sample was subjected to partial dissolution, and the results were considered acceptable only when the ${ }^{14} \mathrm{C}$ ages of at least three aliquots were self consistent within errors. This is the only quantitative test of diagenetic alteration in corals for ${ }^{14} \mathrm{C}$ dating purposes. In addition, conventional screening methods were applied, including textural investigation of thin sections under a petrographic microscope, XRD, and stable isotope analyses. For these reasons, results obtained in the present study are considered as reliable as can be ascertained with presently available methods. However, in some circumstances, it is still possible that contaminated samples could pass through the above tests. For example, the high ${ }^{14} \mathrm{C}$ excesses found in $\approx 50 \mathrm{ka}$ (calendar age) corals, although supported by recent dating of Lake Lisan sediments (Schramm et al. 2000), may need further work for confirmation. In addition to tests for ${ }^{14} \mathrm{C}$ contamination, the samples were tested for open system behavior for $\mathrm{U}$ and $\mathrm{Th}$ isotopes, such as total $\mathrm{U}$ and ${ }^{232} \mathrm{Th}$ concentrations, and $\delta^{234} \mathrm{U}(\mathrm{T})$ values. Most samples were within acceptable limits of these tests.

The results of the ${ }^{14} \mathrm{C}$ time-scale calibration experiments can be summarized as follows: First, the trend for increasing divergence between ${ }^{14} \mathrm{C}$ ages and calendar ages appears to continue beyond $30 \mathrm{ka}$ and up to $50 \mathrm{ka}$; the limit of present measurements. At the younger end, data from the present study overlap with previous data. Second, four discrete age peaks of enhanced ${ }^{14} \mathrm{C}$ concentration were observed. The clustering in age is expected as the samples come from distinct, individual reef sections. However, the prominent peaks of $\Delta^{14} \mathrm{C}$, including some negative values, in between the peaks, were unexpected. It is possible that the peaks are due to secondary, younger age, or modern carbon contamination. While this is acknowledged, and some of the older $\approx 50$ ka samples may have been affected, it is unlikely to be the dominant cause given the battery of tests the samples were required to pass. The negative values of $\Delta{ }^{14} \mathrm{C}$, that systematically cluster in between the peaks, could not be produced by such contamination.

The four ${ }^{14} \mathrm{C}$ peaks appear correlated with the timing of North Atlantic Heinrich Events and ice-rafted debris deposits in deep sea cores. The accepted explanation for these Dangaard-Oeschger and Bond cycles involve reorganizations in the global ocean circulation system. The North Atlantic deep-water formation during glacial periods appears to be sensitive to fresh meltwater input into the North Atlantic by periodic instabilities in the ice sheets that launched armadas of icebergs into Hudson Bay and resulted in sea-level rises. Slow-down or closure of the circulation is expected to significantly raise atmospheric ${ }^{14} \mathrm{C}$ levels. The present data show an initial high sea-level followed by steep rise in atmospheric ${ }^{14} \mathrm{C}$ levels as the sea-level falls. The high concentration lasts for less than $\approx 1000 \mathrm{yr}$ and drops below original ambient levels over several thousand years. The negative values of $\Delta^{14} \mathrm{C}$ indicate the vigorous restart of the NADW circulation or enhanced ventilation at other oceans. Deep water formation around the Antarctic continent is believed to be equal to that in the North Atlantic. Cessation of the North Atlantic circulation is likely to redirect warm equatorial waters to the Southern Ocean and coupled with a high sea-level pulse is likely to destabilize the Antarctic ice sheet as well. ${ }^{14} \mathrm{C}$ and Th$\mathrm{U}$ results obtained in the present work constitute a direct confirmation of severe and abrupt climate oscillations observed in Greenland ice cores and deep sea sediments. They provide direct evidence for the start-stop behavior of the North Atlantic conveyor belt circulation during the last glacial as put forward mainly by Wallace S Broecker (1998), and the increasingly evident global influence of these events beyond the boundaries of North Atlantic.

\section{ACKNOWLEDGMENTS}

We thank GS Burr, PU Clark, and J Jouzel for their helpful comments, and J van der Plicht for editorial assistance. Some of the coral samples were AMS dated at ANSTO supported by AINSE grant (97/ 060R). 


\section{REFERENCES}

Aldahan A, Possnert G. 1998. A high resolution ${ }^{10} \mathrm{Be}$ profile from deep sea sediment covering the last $70 \mathrm{ka}$ : indication for globally synchronized environmental events. Quaternary Geochronology 17:1023-32.

Andrews JT. 1998. Abrupt changes (Heinrich Events) in late Quaternary North Atlantic marine environments: a history and review of data and concepts. Journal of Quaternary Sciences 13(1):3-16.

Banner JL, Wasserburg GJ, Chen JH, Humphery JD. 1991. Uranium-series evidence on diagenesis and Hydrology in Pleistocene carbonates of Barbados, West Indies. Earth and Planetary Science Letters 107:129_ 37.

Bar-Matthews M, Wasserburg GJ, Chen JH. 1993. Diagenesis of fossil coral skeletons: correlation between trace elements, textures and ${ }^{234} \mathrm{U} / 238 \mathrm{U}$. Geochimica et Cosmochimica Acta 57:257-76.

Bard E, Hamelin B, Fairbanks RG. 1990a. U-Th ages obtained by mass spectrometry in corals from Barbados: sea level during the past 130,000 years. Nature 346 : 456-8.

Bard E, Hamelin B, Fairbanks RG, Zindler A. 1990b. Calibration of the ${ }^{14} \mathrm{C}$ timescale over the past 30,000 years using mass spectrometric U-Th ages from Barbados corals. Nature 345:405-10.

Bard E, Fairbanks, RG, Zindler A, Mathieu G, Arnold M. 1990c. U/Th and ${ }^{14} \mathrm{C}$ ages of corals from Barbados and their use for calibrating the ${ }^{14} \mathrm{C}$ time scale beyond 9000 years B.P. Nuclear Instruments and Methods in Physics Research B52:461-68.

Bard E, Fairbanks RG, Hamelin B, Zindler A, Hoang CT. 1991. Uranium-234 anomalies in corals older than 150,000 years. Geochimica et Cosmochimica Acta 55:2385-90.

Bard E, Arnold M, Fairbanks RG, Hamelin B. 1993. ${ }^{230} \mathrm{Th}-{ }^{234} \mathrm{U}$ and ${ }^{14} \mathrm{C}$ ages obtained by mass spectrometry on corals. Radiocarbon 35(1):191-9.

Bard E. 1998. Geochemical and geophysical implications of the radiocarbon calibration. Geochimical et Cosmochimica Acta 62:2025-38.

Bard E, Arnold M, Hamelin B, Tisnerat-Laborde N, Cabioch, G. 1998. Radiocarbon calibration by means of mass spectrometric ${ }^{230} \mathrm{Th} /{ }^{234} \mathrm{U}$ and ${ }^{14} \mathrm{C}$ ages of corals. An updated data base including samples from Barbados, Mururoa and Tahiti. Radiocarbon 40(3):108592.

Bathurst RGC. 1968. Precipitation of ooids and other aragonitic fabrics in warm seas. In: Müller G, Friedman $\mathrm{G}$, editors. Recent development in carbonate sedimentology in Central Europe, Springer-Kerlag. 1-10.

Becker B, Kromer B. 1993. The continental tree-ring record-absolute chronology, ${ }^{14} \mathrm{C}$ calibration and climatic change at $11 \mathrm{ka}$. Palaeogeography Palaeoclimatology Palaeoecology 103:67-71.

Broecker WS. 1997. Thermohaline circulation, the Achilles Heel of our climate system: will man-made
$\mathrm{CO}_{2}$ upset the current balance? Science 278:1582-8.

Broecker WS. 1998. Paleocean circulation during the last deglaciation: a bipolar seesaw? Paleoceanography 13(2):119-21.

Brown TA, Southon JR. 1997. Corrections for contamination background in AMS ${ }^{14} \mathrm{C}$ measurements. $\mathrm{Nu}$ clear Instruments and Methods in Physics Research B123:208-13.

Burr GSE, Edwards RL, Donahue DJ, Druffel ERM, Taylor FW. 1992. Mass Spectrometric ${ }^{14} \mathrm{C}$ and U-Th measurements in coral. Radiocarbon 34(3):611-18.

Chappell J. 1974. Geology of coral terraces, Huon peninsula, New Guinea: a study for Quaternary tectonic movements and sea-level changes. Geological Society of America Bulletin 85:553-70.

Chappell J, Omura A, Esat T, McCulloch M, Pandolfi J, Ota Y, Pillans B. 1996. Reconciliation of late Quaternary sea levels derived from coral terraces at Huon Peninsula with deep sea oxygene isotope records. Earth and Planetary Science Letters 141:227-36.

Chen JH, Curran HA, White B, Wasserburg GJ. 1991. Precise chronology of the last interglacial period: ${ }^{234} \mathrm{U}-230 \mathrm{Th}$ data from fossil coral reefs in the Bahamas. Geological Society of America Bulletin 103:82-97.

Clark PU, Alley RB, Keigwin LD, Licciardi JM, Johnsen SJ, Wang H. 1996. Origin of the first global meltwater pulse following the last glacial maximum. Paleoceanography 11(2):563-77.

Donahue DJ, Linick TW, Jull AJT. 1990. Isotope-ratio and background corrections for accelerator mass spectrometry radiocarbon measurements. Radiocarbon 32(2):135-142.

Edwards RL, Chen JH, Wasserburg GJ. 1986. ${ }^{238} \mathrm{U}-234 \mathrm{U}-$ ${ }^{230} \mathrm{Th}-{ }^{232} \mathrm{Th}$ systematics and precise measurement of time over the past 500,000 years. Earth and Planetary Science Letters 81:175-192.

Edwards RL, Chen JH, Ku T-L, Wasserburg GJ. 1987. Precise timing of the Last Interglacial Maximum from mass spectrometric determination of Thorium-230 in corals. Science 236:1547-53.

Edwards RL, Taylor FW, Wasserburg GJ. 1988. Dating earthquakes with high-precision thorium-230 ages of very young corals. Earth and Planetary Science Letters 90:371-81.

Edwards RL, Beck JW, Burr GS, Donahue DJ, Chappell JMA, Bloom AL, Druffel ERM, Taylor FW. 1993. A large drop in atmospheric ${ }^{14} \mathrm{C} /{ }^{12} \mathrm{C}$ and reduced melting in the Younger Dryas, documented with ${ }^{230} \mathrm{Th}$ ages of corals. Science 260:962-8.

Esat T. 1995. Charge collection thermal ion mass spectrometry of thorium. International Journal of Mass Spectrometry and Ion Processes 148:159-70.

Fifield K, Allan GL, Ophel TR, Head J. 1992. Accelerator mass spectrometry of ${ }^{14} \mathrm{C}$ at The Australian National University. Radiocarbon 34(3):452-7.

Gallup CD, Edwards RL, Johnson RG. 1994. The timing 
of high sea levels over the past 200,000 years. Science 263:796-800.

Hamelin B, Bard E, Zindler A, Fairbanks RG. 1991. ${ }^{234} \mathrm{U} /{ }^{238} \mathrm{U}$ mass spectrometry of corals: how accurate is the U-Th age of the last interglacial period? Earth and Planetary Science Letters 106:169-80.

Hotchkis MAC, Fink D, Hua Q, Jacobsen GE, Lawson EM, Smith AM, Tuniz, C. 1996. High-precision radiocarbon measurements at the ANTARES AMS centre. Nuclear Instruments and Methods in Physics Research B1 13:457-60.

Kitagawa H, Masuzawa T, Nakamura T, Matsumoto E. 1993. A batch preparation method for graphite targets with low background for AMS ${ }^{14} \mathrm{C}$ measurements. $\mathrm{Ra}$ diocarbon 35(2):295-300.

Kitagawa H, van der Plicht J. 1998. Atmospheric radiocarbon calibration to 45,000 yr B.P.: late glacial fluctuations and cosmogenic isotope production. Science 279:1187-90.

Klug HP, Alexander LR. 1974. X-ray diffraction procedures for polycrystalline and amorphous materials. John Wiley \& Sons. 966 p.

Kromer B, Spurk M. 1998. Revision and tentative extension of the tree-ring ${ }^{14} \mathrm{C}$ calibration 9200 to $11,900 \mathrm{cal}$ BP. Radiocarbon 40(3):1117-25.

Ku T-L, Ivanovich M, Luo S. 1990. U-series dating of last interglacial high sea stands: Barbados revisited. Quaternary Research 33:129-47.

Lighty RG. 1985. Preservation of internal reef porosity and diagenetic sealing of submerged early Holoncene Barrier Reef, Southeastern Florida shelf. In: Schneidermann N, Harris PM. editors. Carbonate Cements. Society of Economic Palaeontologists and Mineralogists Special Publication 36:123-51.

Lund DC, Mix AC. 1998. Millennial-scale deep water oscillations: reflections of the North Atlantic in the deep Pacific from 10 to $60 \mathrm{ka}$. Paleoceanography 13(1):1019.

McNichol AP, Gagnon AR, Jones GA, Osbone EA. 1992. Illumination of a black box: analysis of gas composition during graphite target preparation. Radiocarbon 34(3):321-9.

Moore CH. 1989. Carbonate diagenesis and porosity; development in sedimentology. Amsterdam: Elsevier.

Nelson DE, Korteling RG, Stott WR. 1977. Carbon-14: direct-detection at natural concentrations. Science 198:507-8.

Omura A, Ise A, Sasaki K, Takashi S, Hasebe Y. 1995. Resolution and reliability of the $\alpha$-spectrometric ${ }^{230} \mathrm{Th} /{ }^{234} \mathrm{U}$ Method for age determination. Quaternary Research (Japan) 34:195-207.

Ota Y. 1994. Study on coral reef terraces of the Huon Peninsula, Papua New Guinea. Yokohama, Yokohama National University Press. 171p.

Rozanski K, Stichler W, Gonfiantini R, Scott EM, Beukens RP, Kromer B, van der Plicht J. 1992. The IAEA
${ }^{14} \mathrm{C}$ intercomparison exercise 1990. Radiocarbon 34(3):506-19.

Schramm A, Stein M, Goldstein SL. 2000. Calibration of the ${ }^{14} \mathrm{C}$ time scale to $>40 \mathrm{ka}$ by ${ }^{234} \mathrm{U}_{-} 230 \mathrm{Th}$ dating of Lake Lisan sediments (last glacial Dead Sea). Earth and Planetary Science Letters 175:27-40.

Siegenthaler U, Heimann M, Oeschger H. $1980 .{ }^{14} \mathrm{C}$ variations caused by changes in the global carbon cycle. Radiocarbon 22(2):177-91.

Stein M, Wasserburg, GJ, Aharon P, Chen JH, Zhu ZR, Bloom A, Chappell J. 1993. TIMS U-series dating and stable isotopes of the last interglacial event in Papua New Guinea. Geochimica et Cosmochimica Acta 57: 2541-54.

Stirling CH, Esat TM, McCulloch MT, Lambeck K. 1995. High-precision U-series dating of corals from Western Australia and implications for the timing and duration of the Last Interglacial. Earth and Planetary Science Letters 135:115-30.

Stirling CH. 1996. Hig-precision U-series dating of corals from Western Australia: implications for Last Interglacial sea-levels. The Australian National University.

Stirling CH, Esat TM, Lambeck K, McCulloch MT. 1998. Timing and duration of the Last Interglacial: evidence for a restricted interval of widespread coral growth. Earth and Planetary Science Letters 160: 745-62.

Stocker TF, Write DG. 1998. The effect of a succession of ocean ventilation changes on ${ }^{14} \mathrm{C}$. Radiocarbon 40(1):359-66.

Strasser A, Strohmenger C. 1997. Early diagenesis in Pleistocene coral reefs, southern Sinai, Egypt: response to tectonics, sea-level and climate. Sedimentology 44:537-58.

Stuiver M, Polach HA. 1977. Reporting of ${ }^{14} \mathrm{C}$ data. Radiocarbon 19(3):355-63.

Veeh HH, Veevers JJ. 1970. Sea-level at $-175 \mathrm{~m}$ off the Great Barrier Reef 13,600 to 17,000 years ago. Nature 226:536-7.

Voelker AHL, Sarnthein M, Grootes PM, Erlenkeuser H, Laj C, Mazaud A, Nadeau M-J, Schleicher M. 1998. Correlation of marine ${ }^{14} \mathrm{C}$ ages from th Nordic seas with the GISP2 isotope record: implications for radiocarbon calibration beyond $25 \mathrm{ka}$. Radiocarbon 40(1): 517-34.

Vogel JS, Southon JR, Nelso DE, Brown TA. 1984. Performance of catalytically condensed carbon for use in accelerator mass spectrometry. Nuclear Instruments and Methods in Physics Research B5:289-93.

Zhu ZR, Wyrwoll K-H, Collins LB, Chen JH, Wasserburg GJ, Eisenhauer A. 1993. High-precision U-series dating of Last Interglacial events by mass spectrometry: Houtman Abrolhos Islands, western Australia. Earth and Planetary Science Letters 118:281-93. 